Cell Research(1995),5,1-7

\title{
Chromosomal localization of ribosomal DNA sequences in an apple rootstock using a digoxygenin detection system $^{1}$
}

\author{
ZHU JIMEI*, S E GARDINER* \\ The Horticulture and Food Research Institute of New \\ Zealand Limited \\ *Mt AlGert Research Centre, Private Bag 92 169, Auck- \\ land, New Zealand \\ **Batchelar Research Centre, Private Bag 11030 , \\ Palmerston North, New Zealand
}

\begin{abstract}
A $6 \mathrm{~kb}$ rDNA probe comprising the $18 \mathrm{~S}$ coding plus spacer sequences has been hybridized to the metaphase chromosomes of apple rootstock cultivar MM106 demonstrating the localization of ribosomal gene arrays in the vicinity of the telomeric regions of the short arms of chromosomes 6 and 14. The in situ results using digoxygenin labelling coupled to an alkaline phosphatase immunoassay were confirmed by silver staining for NORs and nucleoli. This study demonstrates the feasibility of molecular cytogenetic analysis of very small chromosomes $(1.0-2.7 \mu \mathrm{m})$ of apple.
\end{abstract}

Key words: Malus, chromosomes, in situ hybridization, karyotype analysis, silver staining.

\section{INTRODUCTION}

Our group is currently developing non-radioactive systems for the in situ hy-bridization of DNA markers to the chromosomes of apple (Malus sp.) in order to assign marker linkage groups to physical chromosomes and aid mapping of the apple genome[1-3]. Determination of the location of genes and repeat sequences by in situ

1. Dedicated to Professor Zhen YAO. 
hybridization of biotinylated probes to metaphase preparations has been reported in several plant species with larger chromosomes than Malus including Allium[4], Pisum[5, 6], Crdpis[7], Picea[8] and Triticum[9-11]. However, there has been limited work so far on plant species with very small chromosomes where cytogenetic analysis is more diffcult. There are two recent reports on karyotype analysis for Arabidopsis which has chromosomes of comparable size but fewer in number $(2 \mathrm{n}=10)$ than Malus $(2 \mathrm{n}=34)[12,13]$. This group used digoxygenin labelling coupled with a fluorescent detection system to determine the chromosomal localization of rDNA $(9 \mathrm{~kb}$ probel and of a smaller tandem repeat sequence( $380 \mathrm{bp}$ probe). Although there is a recent report[81 of successful in situ hybridization to chromosomes of a woody gymnosperm (Picea), there are no such reports for woody angiosperms.

This paper describes the use of digoxygenin-labelled apple rDNA sequences(18S coding sequence plus spacer)as a probe along with an enzyme-1inked colour reaction to hybridize to MM106 chromosomes. The position of the nucleolar organiser regions, the site of ribosomal RNA transcription[14,15] was determined by silver staining to provide independent verification of the rDNA probe results. The number of active ribosomal gene loci can also be confirmed by counting nucleoli (sites of ribosome biogenesis)in interphase nuclei[13, 14, 16-18].

\section{MAI'ERIALS AND METHODS}

\section{Plant material}

Actively growing root tips were harvested from glasshouse-grown cuttings of the apple rootstock 'MM106' 'Northern Spy' (Malus x domestica Borkh.) x Malling I-derived from M. paradisia[19],

\section{Preparation of mitotic chromosome spreads and Giemsa staining}

Root tips were pretreated with a saturated paradichlorobenzene solution for 5-6 h at room temperature, rinsed in distilled water for $5 \mathrm{~min}$ and fixed in freshly prepared acidic acid / ethanol (1:3) at $4^{\circ} \mathrm{C}$ overnight. Cell walls were hydrolysed by incubation in a solution of $2 \%$ cellulase and $2 \%$ pectinase(Calbiochem-Behring)at $\mathrm{pH} 4.5$ for $90-120 \mathrm{~min}$ at $37^{\circ} \mathrm{C}$. Roots were washed 2-3 min in distilled water and transferred to $45 \%$ acetic acid before scraping out, macerating. and squashing the meristematic cells. Preparations were frozen in liquid air, coverslips were removed and slides were immersed in 95\% ethanol for 30-60 min before air drying and then stored at- $70^{\circ} \mathrm{C}$. Following Giemsa staining[20], mitotic spreads with cleanly separated chromosomes were identified, photographed under an on objective and karyotypes prepared (Fig 1A).

\section{In situ hybridisation}

The rDNA used as a probe (a gift from Dr. C J Simon)was a $6 \mathrm{~kb}$ rDNA fragment from genomic DNA isolated from the crab apple 'Whire Angel' cloned into pUCl3. It included an 18S coding region and an intergenic spacer[21]. The fragment was excised with Eco RI and then labelled with digoxygenin-dUTP by random priming according to the manufacturer's instructions (Boehringer Mannheim GmBh).

Prior to hybridisation, metaphase chromosome preparations were destained in acetic acid ethanol (1:3 ) for approximately 5-10 mih, transferred to $95 \%$ ethanol, and air dried. The slides were treated with DNase-free RNase $\mathrm{f}(100 \mu \mathrm{g} / \mathrm{ml}$ in $2 \times \mathrm{SSC})$ for $60 \mathrm{~min}$ at $37^{\circ} \mathrm{C}$, rinsed briefly in $2 \times \mathrm{SSC}$ at room temperature, and incubated for $30 \mathrm{~min}$ in $2 \times \mathrm{SSC}$ at $70^{\circ} \mathrm{C}$ before dehydration through $70 \%$, 
95\% and 100\% ethano1. Slides were then air dried.

Twenty-five $\mu$ l of hybridisation mixture (20-40 ng of digoxygenin labelled probe in $6 \times \mathrm{SSC}$, $45 \%$ formamide and $5 \times$ Denhardt's solution) was placed on each side, covered with a siliconized coverslip $(22 \times 22 \mathrm{~mm})$ and sealed with a fast-drying glue. Denaturation was performed by placing slides on a hot plate at $84.5-85{ }^{\circ} \mathrm{C}$ (fmonitored by a thermopile) for 7-10 min and quenching was carried out on ice for $5 \mathrm{~min}$. Hybridization was performed overnight in a humidity chamber at $40^{\circ} \mathrm{C}$. After removing the coverslips, slides were washed thoroughly three times with $2 \times \mathrm{SSC}$ at room temperature for $5 \mathrm{~min}$, with PBS and 0.1\%Triton X-100 for 3 rain and then again three times in PBS.

Controls included either a preparation pretreated with $50 \mu \mathrm{g} / \mathrm{ml}$ DNase for 30 min at $37^{\circ} \mathrm{C}$ or a normal preparation carried through the hybridization procedure but without a probe.

Detection of sites of hybridization of the digoxygenin-labelled probe with an antibody-enzyme conjugate (anti-digoxygenin-alkaline phosphatase) and its visualisation by an enzyme-linked colour reaction (substrates BCIP/NBT) was according to the manufacturer's instructions (Boehringer Mannheim $\mathrm{GmbH}$ ). The preparations were photographed and the sites of hybridization assigned to specific chromosomes according to the Giemsa karyotype.

\section{Silver staining of nucleolar organiser regions(NORs)}

Giemsa-stained metaphase chromosome preparations were first destained, and then re-stained with silver nitrate according to either one of two equally successful methods. Following the procedure of Lacadena et a1.[17], 3-4 drops of freshly prepared 0.7\% (w/v) aqueous silver nitrate(adjusted to $\mathrm{pH} 3.0$ with formic acid) on chromosome preparations, spread on slildes covered with coverslips and incubated overnight in a humidity chamber at $50^{\circ} \mathrm{C}$. The other technique involved the one-step colloidal silver method as described by Howell and Black[22]. Sites of intense black staining (NORs) were assigned to chromosomes. Sites of brown or diffuse staining were non-specific in nature and were ignored.

\section{Chromosome measurements}

Measurements were made from photographs of eighteen metaphase spreads for all three types of staining and relative length, arm ratio, were calculated according to Macgregor and Varley[20].

\section{Detection of nucleoli}

Interphase cells from root tips were stained by the aqueous silver nitrate/colloidal developer method of Howell and Black[22].

\section{RESULTS and DISCUSSION}

Analysis of eighteen metaphase spreads stained by Giemsa, silver staining, and in situ hybridization confirmed that 'MM106' is a diploid $(2 \mathrm{n}=34)$ and that its chromosomes can be arranged in seventeen pairs (Figs 1 and 2) [23].The measurements of relative chromosome length, and arm ratio indicated that a11 the chromosomes are submetacentric (Tab 1). Their size ranged from $1.0-2.7 \mu \mathrm{m}$, which is slightly larger than reported earlier $(0.5-1.0 \mu \mathrm{m})$ by Lespinasse et a1.[23]. Secondary constrictions which have been associated with plant NORs in some studies $[4,5,10,16,24]$ were not observed.

Hybridization of the rDNA sequence was detected at a $90 \%$ frequency(over ten preparations) as patches of dark purplish-brown precipitate at the end of the short arms of chromosomes 6 and 14 (Fig 1b), while control preparations(either DNase 
Chromosomal localization of ribosomal DNA sequences in apple

pretreatment of chromosomes or hybridization without a probe) failed to give such a colour reaction.

Nucleolar organiser regions stained with silver were visible as tight black spots whereas non-specific staining was yellowish brown and tended to be more diffuse. The ten preparations examined indicated the presence of NORs at a frequency of $70 \%$ for chromosome 6 and $90 \%$ for chromosome 14 . NORs were present at the end of the short arms for both chromosome pairs. These results confirm the localization of ribosomal RNA genes detected with in situ hybridisation by the rDNA probe (Fig 2) since the acidic silver staining of ribonucleic protein accumulating around active NORs in interphase and remaining at mitosis is an indication of gene activity at rDNA sites during the

Tab 1.Chromosome measurements for apple rootstock 'MM106' (mean of eighteen metaphase preparations with results pooled for the three methods of staining).

\begin{tabular}{ccc}
\hline $\begin{array}{c}\text { Chromosome } \\
\text { number }\end{array}$ & $\begin{array}{c}\text { Relative } \\
\text { length }\end{array}$ & Arm ratio \\
\hline 1 & 8.70 & 2.14 \\
2 & 7.77 & 1.77 \\
3 & 7.34 & 2.20 \\
4 & 7.01 & 2.24 \\
5 & 6.76 & 2.15 \\
6 & 6.53 & 1.80 \\
7 & 6.30 & 2.06 \\
8 & 5.97 & 2.04 \\
9 & 5.77 & 2.03 \\
10 & 4.43 & 1.94 \\
11 & 5.30 & 1.85 \\
12 & 5.07 & 2.22 \\
13 & 4.83 & 1.76 \\
14 & 4.67 & 1.66 \\
15 & 4.56 & 1.76 \\
16 & 4.23 & 1.71 \\
17 & 3.77 & 1.59 \\
\hline
\end{tabular}

All chromosomes are submetacentric. preceding interphase[14].

When silver stained interphase preparations were screened to determine the maximum number of nucleoli and hence number of active rDNA loci, most interphase nuclei were found to contain one large nucleolus formed by complete fusion of nucleoli during the cell cycle, but few contained two, three, or the primary number of four[25], indicating that all four rDNA loci can be active as reported for AraNdopsis[13]. The nucleoli were of two size classes (Fig 3), reflecting differences in amount or rate of transcription at the rDNA loci on chromosome pairs 6 and 14, or difierent rates of assembly or export of ribosomes[26].

Onr finding that rDNA genes in Malus are localized on two pairs of chromosomes is consistent with earlier in situ hybridization for the diploid angiosperm species including A1lium cepa, A. fistulogum, AraNdopsis thaliana, Pisum sativum, and Hordeum vulgare. In contrast in Secale cereale hybridization only one pair of chromosomes has been reported $[4,5,13,24]$.

\section{CONCLUSIONS}

The combination of in situ hybridization of metaphase preparations with a homologous rDNA probe with acidic silver staining of NORs and nucleoli has enabled 

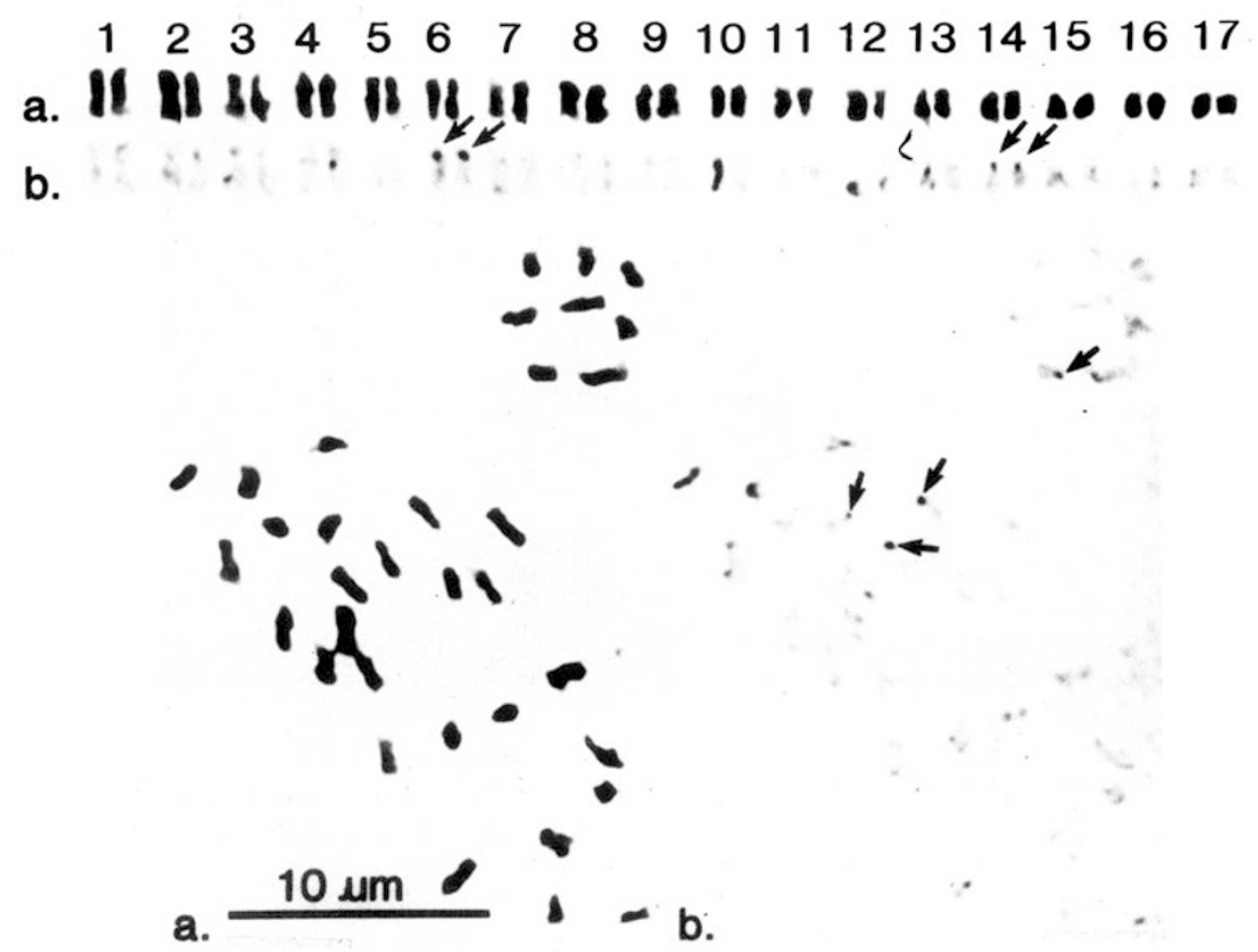

Fig 1. Root tip metaphase chromosome spread of apple rootstock 'MM106' with karyotype. a. Giemsa staining.

b. In situ hybridization with an $18 \mathrm{~S}$ plus spacer rDNA probe detected with the alkaline phosphatase-linked immunoassay. Sites are indicated by arrows.

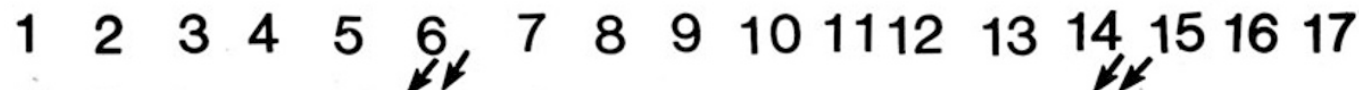

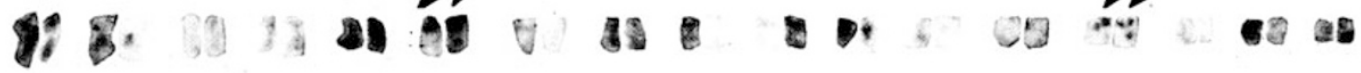

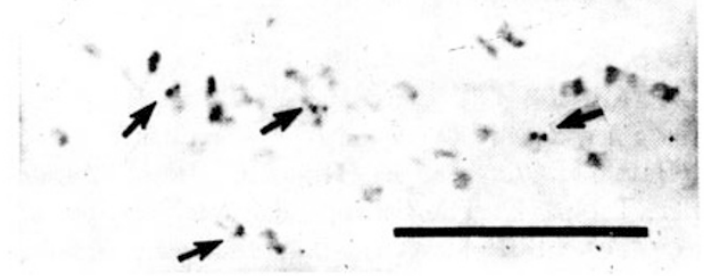

Fig 2. Silver staining of root tip metaphase chromosomes of apple rootstock 'MM106'. Ar-. rows indicate NORs on spread and karyotype. Bar: $10 \mu \mathrm{m}$ 


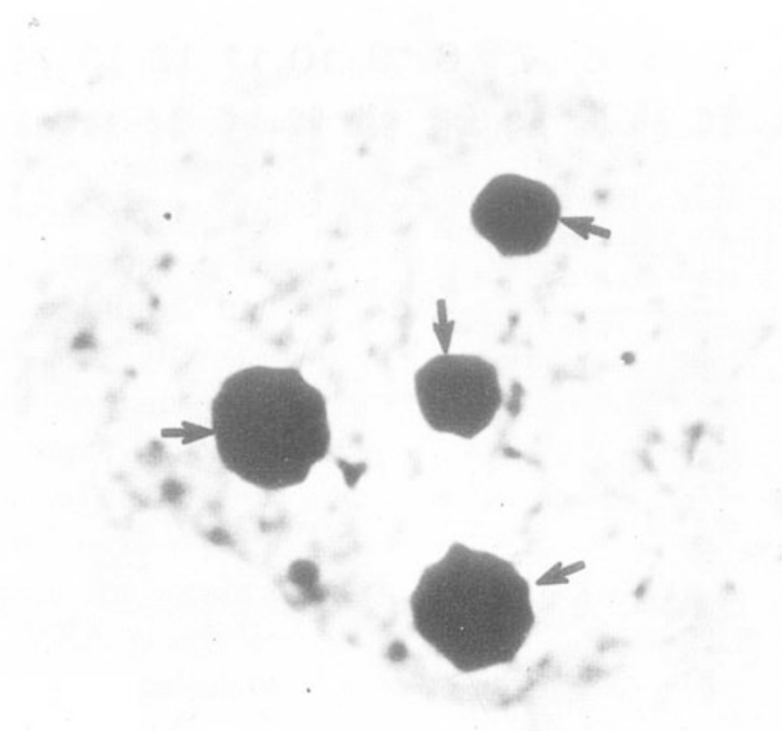

\section{0 um}

Fig 3 . Silver-stained interphase nucleus of apple rootstock 'MM106' showing 4 nucleoli.

the assignment of rDNA genes to the telomeric regions of the short arms of chromosomes 6 and 14 in the apple rootstock 'MM106'. The digoxygenin labelling of the probe coupled with an antibody-alkaline phosphatase colour detection system proved to be a sensitive, reliable and rapid method for the identification of sites of hybridization to small chromosomes (1.0-2.7 $\mu \mathrm{m}$ ) of this woody perennial.

Future studies for in sjtu hybridization to apple chromosomes will ultimately relate information from linkage maps to the physical chromosomes.

\section{Acknowledgement}

This research was funded by the New Zealand Foundation for Research, Science and Technology, Contract Number C06209.

\section{REFERENCES}

[1] King GJ, Alston FH, Battle I, Chevreau E, Gessler C, Janse J, Lindhout P, Mangan aris AG, Sansavini S, Schmidt H, Tobutt K. The 'European apple genome mapping project-developing a strategy for mapping genes coding for agronomic characters in tree species. Euphytica, 1991; 56:89-94.

[2] Hemmat M, Weeden NF, Manganaris AG, Lawson DM. Molecular marker linkage map for apple. J Hered, 1994; 85(1): 4-11.

[3] Gardiner SE, Whitehead HCM, Yeates AJ. Strategies for gene mapping in apples (Malus) In: Abstracts of Australian gene mapping and molecular genetics symposium. University of Otago, 


\section{Zhu JM and SE Gardiner}

New Zealand. 1991: p36.

[4] Ricroch A, Peffley EB, Baker RJ. Chromosomal location of rDNA in Allium: in situ hybridization using biotin- and fluorescein-labelled probe. Theor Appl Genet, 1992; 83: 413.8.

[5] Rawlins DJ, Shaw PJ. Three-dimensional organisation of ribosomal DNA in interphase nuclei of Pishin sativum by in situ hybridization and optical tomography. Chromosoma, 1990; 99:143-51.

[6] Simpson PR, Newman MA,. Davies DR. Detection of legumin gene DNA sequences in pea by in situ hybridization. Chromosoma, 1988; 96: 45-4.8.

[7] Ambros PF, Matzke MA, Matzke AJM. Detection of a $17 \mathrm{~kb}$ sequence (T-DNA) in plant chromosomes by in situ hybridization. Chromosoma, 1986; 94:11-8.

[8] Brown GR, Amarasinghe V, Kiss G, CarIson JE. Preliminary karyotype and chromosomal localization of ribosomal DNA sites in white spruce using fuorescence in situ hvbridization. Genome, 1993; 36:310-6.

[9] Gustafson JP, Dera AR, Petrovic S. Expression of modified rye ribosomal RNA genes in wheat. Proc Natl Acad Sci USA, 1988; 85:3943-5.

[10] Mukai Y, Endo TR, Gill BS. Physical mapping of the 18S.26S rRNA multigene family in common wheat: identification of a new locus. Chromosoma, 1991; 100: 71-8.

[11] Rayburn AL, Gill BS. Use of biotin-labeled probes to map scientific DNA sequences on wheat chromosomes. J Hered, 1985; 76: 78-81.

[12] Murata M, Varga F, Maluszynska J, Griindler P, Schweizer D. Chromosomal localization of the ribosomal RNA genes in Arabidopsis thaliana by in situ hybridization. In: Schweizer D, Peuker $\mathrm{K}$, Loidl J (eds). Abstracts of the fourth international conference on Arabidopsis research. Vienna: University of Vienna: 1990:p5.

[13] Maluszynska J, Heslop-Harrison JS. Localization of tandemly repeated DNA sequences in Arabidopsis thaliana. Plant J, 1991;1:159-66.

[14] Hernandez-Verdun D. The nucleolus today. J Cell Sci, 1991; 99:465-71.

[15] Robert-Fortel I, Junéra HR, Gérard G, Hernandez-Verdun D. Three-dimensional organization of the ribosomal genes and Ag-NOR proteins during interphase and mitosis in $\mathrm{PtK}_{\mathrm{l}}$ cells studied by confocal microscopy. Chromosoma, 1993; 102:146-57.

[16] Cermeño MC, Orellana J, Santos JL, Lacadena JR. Nucleolar organizer activity in wheat, rye and derivatives analysed by a silver-staining procedure. Chromosoma, 1984; 89:370-6.

[17] Lacadena JR, Cermeño MC, Orellana J, Santos JL. Evidence for wheat-rye nucleolar competition (amphiplasty) in triticale by silver-staining procedure. Theor Appl Gent, 1984a; 67:207-13.

[18] Lacadena JR, Cermeno MC, Orellana J, Santos JL. Analysis of nucleolar activity in Agropyron elongatum, its amphiploid with Tdticum aestivum and the chromosome addition lines. Theor Appl Genet, 1984b; 68:75-80.

[19] Cummins JN, Aldwinckle HS. Breeding apple rootstocks. Janick J (ed). Plant breeding reviews. Avi Publishing Co, Westport, Conn: 1983; 294-394.

[20] Macgregor HC, Varley JM. Working with animal chromosomes. John Wiley and Sons Ltd, Chichester, New York, Brisbane, Toronto, Singapore: 1983:250pp.

[21] Simon CJ, Weeden NF. Molecular analysis and cloning of Malus ribosomal DNA. J Amet Soc Hort Sci, 1992; 117:164-8.

[22] Howell WM, Black DA. Controlled silver-staining of nucleolus organizer regions with a protective colloidal developer: a 1-step method. Experientia, 1980; 36: 1014-5.

[23] Lespinasse Y, Alston FH, Watkins R. Cytological techniques for use in apple breeding. Ann Appl Bio1, 1976;82:349-53.

[24] Appels R, Gerlach WL, Dennis ES, Swift H, Peacock WJ. Molecular and chromosomal organization of DNA sequences coding for ribosomal RNAs in Cereals. Chromosoma, 1980; 78: 293-311.

[25] Anastassova-Kristeva M. The nucleolar cycle in man. J Cell Sci, 1977; 25:103-10.

[26] Martini G, Flavell R. The control of nucleolus volume in wheat, a genetic study at three developmental stages. Heredity, 1985; 54:111-20.

Received 1-12-1 994

Accepted 2-3-1995. 